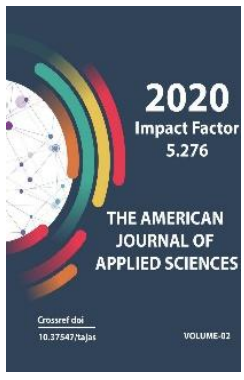

Journal Website: http://usajournalshub.c om/index,php/tajas

Copyright: Original content from this work may be used under the terms of the creative commons attributes 4.0 licence.

\section{The Essence Of Small Business And Private Entrepreneurship And The Theoretical Basis Of Its Development}

\author{
Ravshanjon Baxritdinovich Ismoilov \\ Candidate Of Economic Sciences, Namangan Institute Of Engineering And Technology, \\ Namangan, Republic Of Uzbekistan \\ Baxtiyarjon Bulturbayevich Mullabayev \\ Doctor Of Philosophy In Economics (Phd), Namangan Engineering Construction Institute, \\ Namangan, Republic Of Uzbekistan \\ Zuhrali Tursunalievich Abdulxakimov \\ Senior Lecturer, Namangan Institute Of Engineering And Technology, Uzbekistan \\ Jakhongirbek Ravshanjon Ogli Bakhriddinov \\ Doctoral Student, Namangan Institute Of Engineering And Technology, Uzbekistan
}

\title{
ABSTRACT
}

The article analyzes the need and theoretical basis for the development of small business and private entrepreneurship, based on the analysis of practical proposals and recommendations for the development of the industry and the development of small business and private entrepreneurship. Opinions are given that it has been given importance.

\section{KEYWORDS}

Small businesses, private entrepreneurship, gross domestic product, regional development, the global financial and economic crisis, modernization, and diversification.

\section{INTRODUCTION}

The various positive changes taking place in the economies of countries are inextricably linked with the development of small business and private entrepreneurship. The establishment and development of this industry is influenced by any changes in the business sector. At the same time, the experience of developed economies shows that the steady rise in living standards has been achieved, first of all, through the rapid development of small business and private entrepreneurship. Therefore, the development of business and private entrepreneurship, increasing its place and role 
in the economy is also very important for the people of Uzbekistan. Therefore, in the Republic of Uzbekistan, where market relations are developing, special attention is paid to the development of small business and private entrepreneurship, which is formed on the basis of laws and principles that reflect the development of private property. In the early years of independence, entrepreneurship developed mainly in the service sector. It should be noted that the number of enterprises in the trade and catering sector and the number of workers employed in them is growing rapidly.

\section{MAIN PART}

Completion of the second phase of economic reforms in the field of privatization of state property: the transfer of property to the real owners, the solution of the problem of stimulating a diversified economy, the development of industry and agriculture and processing of agricultural products . In recent years, in a number of developing countries on the basis of a modern market economy, there is a process of implementation of many of the previous tasks performed by giant enterprises by mobile, ie compact, small enterprises. It is for these reasons that the number of large industrial enterprises is declining and the number of small enterprises is growing rapidly. This process is the basis for the dynamic, dynamic, innovative growth of the market economy, the creation and development of small business and private entrepreneurship, which is rapidly adapting to market demand and its changes. Foreign economists give a systematic definition of business. Professors at the University of Texas and the University of Illinois at UrbanaChampaign described Business as shown in Fig 1

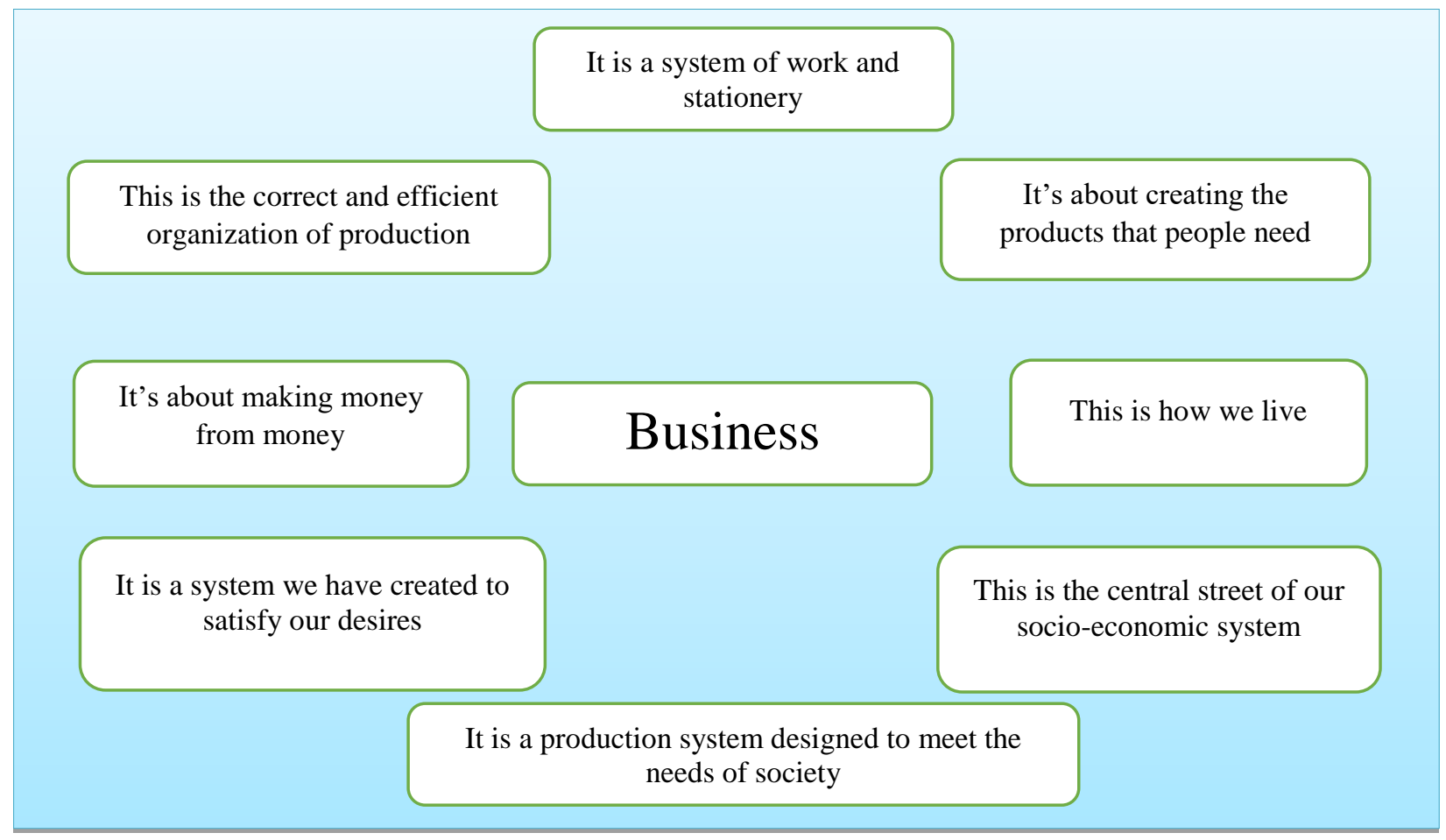

Fig 1. Theoretical views on business formation 
Improving the living standards of the population, increasing real incomes and providing employment through the development of small business and private entrepreneurship is one of today's priorities. Therefore, favorable conditions for the development of entrepreneurship are being created in our country, and this work is yielding positive results.

Small businesses will be able to complement the process of economic reform with their diversity and be recognized as one of the important factors in the transition period. Our comparison of the diversity and breadth of today's consumer market, the fact that the shelves of our stores are filled with a variety of consumer goods, shows that small businesses play an important role in the economy. The objective necessity and certain subjective reasons that have arisen in Uzbekistan condition the emergence and development of small businesses. These conditions and causes can be divided into general and specific groups, and these are shown in. Another advantage of small business and private entrepreneurship is their quick adaptability to demand. Confirming this, it can be said that production is carried out at these enterprises. After all, this is one of the main conditions of the business. In this regard, it is necessary to strengthen the specialization of small businesses and private enterprises in production, to adapt quickly to market conditions, to forecast demand and to conduct production and trade without gypsum.

As a result of measures taken to encourage the development of small business and private entrepreneurship, in 2018, excluding farms and dehkan farms, more than 20,000 new small businesses were established, and their total number exceeded 195,000. The role of enterprises operating in this area in the economy has increased significantly. At the same time, the share of small business and private entrepreneurship in the formation of GDP in 2018 compared to 2000 increased from $31 \%$ to $56.7 \%$, in industrial production from $12.9 \%$ to $32.5 \%$. In 2000 , the number of people employed in small business and private entrepreneurship was $49.7 \%$. As a result of the high effectiveness of measures aimed at the development of small business and private entrepreneurship, which have been consistently implemented in the economy, in 2018 this figure exceeded $76.8 \%$. According to the United Nations, in the global economic system, small business and private entrepreneurship employ 50 percent of the world's working-age population. At present, the volume of production in this sector accounts for $33-68 \%$ of total production. In addition, between 2016 and 2018, about 3.6 million new jobs were created in the United States through small businesses, with a net job growth rate of 65 percent across the country. Today, this sector accounts for 50 percent of GDP in the United States, and small businesses account for 55 percent of the total workforce. In addition, in China, a country with a developed economy, great importance is attached to the prospects of this sector. In particular, the share of small business in the country's GDP is $60 \%$, and $80 \%$ of the population is employed in the sector. In contrast to the economies of the West and the East, the share of small business in the GDP of European countries is $65 \%$, and $70 \%$ of the population is currently employed in this sector [3].

In developed countries, great attention is paid to the introduction of innovations in the economy, especially in the business system. This indicates that in developed market economies, small business and private 
entrepreneurship have become a key factor in economic growth and employment. Therefore, it is expedient to develop this innovative activity in the economy of the Republic in small business and private entrepreneurship.

In the process of further liberalization and deepening of economic reforms in our country, the development of small business and private entrepreneurship is of great importance. The reason for this is:

- Is the basis of the state economy, along with small business and private entrepreneurship;

- The well-being of the country largely depends on the results of small business and private entrepreneurship, timely and prompt attention to demand, the ability to produce the necessary and quality products;

- In the transition period, small business and private entrepreneurship are the locomotive of creating favorable conditions for the development of a market economy.

Analyzes show that an initial investment is very important for a newly established small business or micro-firm to get things done smoothly. The inability of most private enterprises in the country to function properly, and in some cases their closure, is also associated with a lack of start-up capital. Along with a number of opportunities, small businesses in Uzbekistan face a number of challenges. If we look at small enterprises by type of activity, the largest share of enterprises currently operating in the country falls on small enterprises engaged in trade and catering and services. It should be noted that the majority of small businesses and private entrepreneurs are not able to deliver the necessary raw materials on time, and there are a number of problems in the tax system and the proper organization of bank loans. In this regard, it is necessary to take into account that the process of organizing production takes a long time compared to trade and services.

It is necessary to take a number of measures to address the above problems and to further develop small business and private entrepreneurship. Including:

- Encourage domestic and foreign investment in the production of small businesses and private entrepreneurship;

- Expanding the competitive environment between small businesses and private entrepreneurs;

- Prolongation of loans for production and reduction of interest rates;

- Development of exports between enterprises, further improvement of the system of taxation of small business and private entrepreneurship, and in particular the adequacy of the legal framework.

\section{CONCLUSION}

In short, the consistent implementation of these measures will make a significant contribution to the development of small business and private entrepreneurship, especially in overcoming these shortcomings and problems and ensuring the integration of our economy into the world community.

\section{REFERENCES}

1. Robert Sher. A Strong Midsize Business: How To Deal With The Seven Key Barriers to Growth. // Mighty Midsized Companies. How Leaders Overcome 7 Silent Growth Killers. - M .: Alpina Publisher, 2016 . - 248

p. 
2. Abdulkhakimov Z. (2018). Development of regional economy with mountain recreation: in case Uzbekistan. Bulletin of Science and Practice, 4(5), 446-453. http://doi.org/10.5281/zenodo.1246298

3. Abdulhakimov Zuhrali Tursunalievich. (2019). Senior Teacher of the Namangan Engineering and Technology Institute. Scientific and analytical journal "Science and Practice» of Plekhanov University. Vol. 11. No. 1 (33) 79.

4. Abdulxakimov, Z. T., \& Raxmonjonov, R. Sh. (2019). ATTRACTING INVESTMENTS TO THE ECONOMY. Priorities for ensuring the economic security of the country, 1(4),3.retrievedfrom https://journal.tsue.uz/index.php/iqtisodiy _xavfsizlik/article/view/108

5. Zainutdinov Sh., Mullabaev B. Uzbekistonda shtisodiy integration rivozhlantirish va uning samaradorligini oshirish omillari // BIZNES - EXPERT. [Electronic resource], 2018. No. 7 (127). Access mode: http://www.biznesdaily.uz/uz/birjaexpert/60042-uzbkistondaiqtisodiy-intgratsiyani-rivojlantirish-vauning-samaradorligini-oshirish-omillari/ (date of access: 30.07.2018).

6. Mullabaev B.B. Development of light industry branches in Uzbekistan basedon vertical integration // Bulletin of Science and Practice scientific journal No. 10 of 2017 http://www.bulletennauki.com

7. Dilorom Sobirovna, Q., Abdurasul Abdugafarovich, S., \& Baxtiyarjon Bulturbayevich, M. (2019). Improvement of the strategy of vertical integration in industrial enterprises. American Journal of Economics and Business Management, 2(3), 63-68. https://doi.org/https://doi.org/10.31150/aje bm.v2i3.81
8. Mullabayev B. B. Economic analysis of vertical integration integration of the Namangan region (on the prerogative of the Republic of Uzbekistan) // "Science of theory: theory and practice" - 8/2018

9. Mahmudov Baxriddin Jurayevich, Mullabayev Baxtiyarjon Bulturbayevich, ATTRACTING FOREIGN INVESTMENT IN THE AGRICULTURAL ECONOMY, International Engineering Journal For Research \& Development: Vol. 5 No. 2 (2020): IEJRD

10. Mullabayev Baxtiyarjon Bulturbayevich, Shakirova Gulbahor Sharipdjanovna, Alabayev Sobitxon Ibragimovich, Mirzaabdullayeva Gulnora, MODERN FEATURES OF FINANCIAL MANAGEMENT IN SMALL BUSINESSES, International Engineering Journal For Research \& Development: Vol. 5 No. 4 (2020): IEJRD

11. Mahmudov Baxriddin Jurayevich, Mullabayev Baxtiyarjon Bulturbayevich, ATTRACTING FOREIGN INVESTMENT IN THE AGRICULTURAL ECONOMY, International Engineering Journal For Research \& Development: Vol. 5 No. 2 (2020): IEJRD

12. Mullabaev, B. B., Vohidov, E., \& Karimov, D. (2019). ROLE OF VERTICALLY INTEGRATED ENTERPRISES IN THE ECONOMY. Theoretical \& Applied Science , (1), 85-90.

13. Mullabaev, B. B. (2018). ECONOMETRIC ANALYSIS OF VERTICAL INTEGRATION OF THE LIGHT INDUSTRY ENTERPRISES OF THE NAMANGAN REGION (ON THE EXAMPLE OF THE REPUBLIC OF UZBEKISTAN). Scientific Review: Theory and Practice , (8), 22-36.

14. Zaynutdinov, S. N., \& Mullabayev, B. B. (2018). REGIONAL EFFECTIVENESS OF THE REGIONS. Economics and Innovative Technologies, 2018(1), 36. 
15. Bachtijarzhan M. DEVELOPMENT OF LIGHT INDUSTRY BRANCHES IN UZBEKISTAN BASED ON VERTICAL INTEGRATION //Бюллетень науки и практики. - 2017. №. 10 (23).

16. Dadaboyev TY, Qoraboyev SA, Mullabaev BB CORPORATE MANAGEMENT AS THE FACTOR OF INVESTMENT ATTRACTION // Scientific knowledge of the present. - 2017. - No. 5. - S. 77-80.

17. Mullaboev B. B. Corporate governance as a way to attract investment // Young scientist. - 2015. - No. 10. - S. 749-751.

18. Ismoilov R.B., Matkarimov K.Zh., Khaidarov Kh.Kh., Nabotova Z. THE ROLE OF THE TEACHER IN THE EDUCATIONAL PROCESS: ADDRESSED TRAINING OF SPECIALISTS OF SECONDARY PROFESSIONAL EDUCATION IN THE PROCESS OF NETWORK INTERACTION. materials of the IV All-Russian scientificpractical conference with international participation. Institute for the Development of Territorial Systems of Professional Education; FGAOU VO "Russian State Professional Pedagogical University". 2019.S. 167-174. 